\title{
WOMEN AND SUSTAINABLE FISHERIES EXPLOITATION: A REVIEW
}

FRANCIS, AMIYE AND IBIM, ADABA T.

Department of Animal Science and Fisheries, Faculty of Agriculture, University of Port Harcourt, P.M.B. 5323, Port Harcourt.

\begin{abstract}
Sustainability in the extraction of fishery resource need to be proactively upheld if the achievement of the Millennium Development Goals (MDGs) will be anything to go by in Nigeria and other developing countries. The fishery resource, of the biotic component of the environment, and the main focus of this paper, is renewable resource whose existence if not for adverse environmental factors and natural speciation that occurs over thousands of years, is a continuum. The biological attributes of these fauna and flora render them amenable to usage in manners that still allows their continuous existence for the profit of mankind. Ignorance and the consequent inappropriate harvesting methods and uses of the fishery resource make them prone to abuse, imperilment, and eventual extinction. The influential and important roles of women as fishers, fishmongers, processors, concerned citizens of healthy living and organizers of the end use of the fishery resource put women in a vantage position to influence; thereby, enforcing conservation and sustainability in the extraction of the resource when trained in natural resource management. Consequently, women need to be trained and equipped with knowledge such as basic principles in these areas: biological attributes of the aquatic resources, measures of aquatic resource management, and approaches such as co-management, , community-based and ecosystembased approaches to fishery management; including simplified principles embedded within international instruments that form the legal frame work for resource management.
\end{abstract}

\section{Key Words: Women, Sustainable, Fishery Resource, and Exploitation}

\section{INTRODUCTION}

Nigeria being a coastal state, most of its populace lives within rural communities as in all coastal states of the world. Fishers within these communities strive to meet the fish demand of their countries (FAO, 1998; world Bank, 2009). According to the Commission of the European Committee, COM (2000) , 50\% of the world's human population live less than $60 \mathrm{~km}$ from a coast and the increase is expected to reach $70 \%$ by 2020 . The enormous contribution of women in the fisheries sub-sector is well documented ( Shalesha and Stanley, 2000; Alamu and Olowosegun, 2005; Yarhere, 2005; Shinkafi, 2007). These activities, be they in Africa or Asia include; actual fishing, pre- and post- harvest processes, trade, construction and maintenance of the fishing gear. According to Alamu and Olowosegun (2005), 85\% of rural women engage in agricultural activities, fisheries inclusive. Fishery resource is important both to the developed and developing countries. It is estimated that more than 150million poor people in the world depend on the fishery resource for food security and livelihood.

The United Nations produced an eight points Millennium Development Goals (MDGs) to which Nigeria is signatory. Goal seven of the MDGs is to ensure environmental sustainability, the essence of which was in addition to restoration, protection and conservation of natural resource, the reversal of loss of the world's environmental resources, while goal three is the promotion of gender equity and women empowerment

(GreenFacts:

Http://://www.greenfacts.org/en/fisheries/1-2/03-marine-inlandresources.htm.Retrieved107102007). 
With the globally accepted depletion of fish stock, there is need for strategies to be put in place to salvage the livelihood of the rural poor whose day-to-day subsistent living depends on the fishery resource. Such strategies should contain inherent measures to enforce sustainable exploitation of the resource.

The documented roles of women in fish production place them on a pedestal from where they can effectively influence, and thereby enforce sustainable fishery exploitation. The physical, chemical, geological, social as well as the biological components of the environment adversely impact on the fishery and lead to depletion (Speer, 1995). Prominent now is the high human population in coastal areas and this has resulted in high ecological pressure on the narrow continental plateau that is habitat to most maritime resources.

The essence of sustainable fisheries exploitation is that the structures and functions of the aquatic resources and ecosystem be so maintained that mankind can obtain optimum benefits from such resources now and still ensure their availability for future generations. In time past unlike now the state of the environment was regarded as secondary when development was considered (State of the World population, 2006). The World Summit on Sustainable Development (WSSD) and many other international instruments are consequences of the concern to uphold conservation and sustainability in natural resource exploitation.

Today environmental sustainability is a crucial global issue since the environment has a direct bearing on a meaningful and continued existence for man. The realization of this crucial role of the environment has led to the need for natural resource management since these resources are vital components of the environment. This paper discusses the involvement of women in the extraction and use of the fishery resource, why women should be trained in natural resource management, and the profit accruable from such trainings.

\section{Fishery Resource: Importance And Its Sustainable Exploitation}

Fishery resource consists of all classes of aquatic fauna and flora, both of micro and macro in nature that can be cultivated or captured. All classes of aquatic invertebrates and vertebrates are inclusive. According to FAO (2009), both capture fisheries and aquaculture play important roles in securing and enhancing livelihoods of the poor in both in Africa and Asia-Pacific. The Asia-Pacific region alone accounts for about $90 \%$ of the world's aquaculture production. About $75 \%$ of this $90 \%$ is from low-income food deficit countries through their smallholder farms cultivated by means of low value inputs and traditional technologies. (www.streaminititative; Speer, 1995). In 2003 export value of world trade in fish was US\$63 billion and half of this comes from developing countries with global consumption increasing up to 21\% between 1992 and 2002 (World Bank, 2009).

In Nigeria, most households depend on fin fish and shellfish for livelihood especially in the Niger Delta area. The potential for the production and export of fish from the Niger Delta is high when the enormous water body and its associated fish biodiversity is considered. An average of about $90 \%$ protein intake is obtained through fish in these coastal communities it is usually the source of animal protein. The fishery resource is an important source of foreign exchange in many developing countries (Comm., 2000). From UNDP (2003), outcome of women participation in fisheries exploitation include: one, ensuring food security through increased fish availability for family consumption. Two; better economic situation in the family as a result of increased fish production. Three; upliftment in social status through the adoption of new technologies. Four; sustained children education resulting from improved family income. Five; enhanced social capital due to better relationships within the community, for example, in providing information to other women. Six; productive use of time without adding much to the existing workload. Seven; rise in social status and participation in decision-making processes in the family. It was discovered that 
provision of knowledge to fish farmers especially women contributed to women empowerment and increase in family income (UNDP, 2003).

Definitely, management, which has to do with proper allocation and use of resources, is the key to sustainable resource exploitation. That fisheries management Lackey (2005), has been practiced for more than a century now indicates that sustainable exploitation of fisheries resource even in the developing world should be upheld. Sultana and Thompson (2005) have reported on managing aquatic resources for sustainable livelihood of the poor with its accompanying benefits. Such resource management centered on improving technology, employing different forms of aquaculture, with better access to natural stocks of fish and other aquatic organisms. Developing countries are the repositories of most of the fishery resource of the planet earth, but the unregulated and illegal exploitation practices have exposed the fishery to great risks of irrecoverable depletion. This unfavourble condition of the fishery resource demands great attention. FAO (1998) reported that the fishery increased over the last 20 years to 120 million tonnes, reducing drastically, and giving way to outputs of smaller pelagic fish of lower commercial value; and this due to overfishing, increased coastal, marine and freshwater ecosystem degradation with population increase and the consequent overexploitation (World Bank, 2009).

\section{Reasons for sustainable exploitation of the Fishery Resource}

The reasons are numerous, but the few listed here include: one; the extinction of aquatic fauna and flora due to destruction of wild habitat such as mangroves (Rhizopora and Avicennao spp.) either for fuel, aquaculture purposes; or destruction of marsh and swamps for development purposes. More than 31,000 of the world's fauna and flora are threatened with extinction (Mukherjee, 2002). Two; overexploitation of marine organisms through the provision of efficient fishing gears and vessels. Three; the increasing demand for the consumption of fish and its products that poses threat to fish yields through overexploitation. Four; the common property nature of aquatic resources in many coastal African countries, exposes the fauna and flora to overexploitation. Five; the renewable nature of these biotic resources places a demand on its users not to exceed the threshold beyond which their recovery will be hampered. Six; the seasonality of their reproductive life cycles and definite life span should also put a constraint on man not to unduly interfere with such cycles. Seven; Mukherjee (2002) reported that about 500 marine organisms yield chemicals used for medical purposes yet only about $1 \%$ of the world's species has been studied for their potential use for man, leaving the vast untapped reservoir of genes to face the risk of extinction without fulfilling the purpose of their existence for man. Eight; is the increased threat from biodiversity due to habitat destruction, over-harvesting, pollution and inappropriate introduction of exotic organisms

\section{Involvement Of Women In Sustainable Fisheries Exploitation}

According to COM (2000) one of the Internationally agreed principles on aquatic resource-based development include making local communities (i.e. community members and local authorities) play vital role in the management and development of the environment because of their traditional practices and knowledge of the resources. There are case studies that reveal the higher efficiency of women in sustainable fisheries exploitation than do men. In the Philippines, COMM (2000), community-based coastal resource management program, with gender perspective, was adopted to address problem of aquatic resource depletion. Five principles of community-based coastal resource management (CBCRM) used in the project were: empowerment, sustainability, equity, systems orientation and gender. This participatory project showed that the men were involved in actual fishing while the women took up the pre-and post fishing activities, maintenance of nets and tools, and preparation of meals and baits for the fishing trips. The recommendation from this project was that women were primarily interested in improving the condition of coastal resources. Sultana and Thompson 
(2005), reporting on the community-based (CBOs) management of a seasonal flood plain in Bangladesh observed, that the management activities at the research sites showed women to played more effective role in the CBOs than men. Also, the women, unlike the men were able to influence women in the women-led site while both men and women realized that decision over the fishery and active management improved. However, the women had a more diverse set of criteria for effective CBOs than men. Men-only CBO saw itself as more of a membership based organization than representing the community. Such gender perspectives were used in Madagascar also (Wildlife conservation society, 2006).

Many International instruments such as the Dublin Conference of 1992, the World Summit on Sustainable Development in 1992, the Beijing conference 1995 etc. have endorsed participation of stakeholders in the management of aquatic resources. Such endorsement point to the need of using informed stakeholders.

\section{The Need To Train Women In Resource Management}

Modern approaches of resource management such as the participatory approach require the participation of all stakeholders in the planning, designing, execution, monitoring and evaluation phases of the resource management program. Encouraging results of sustainable exploitation of the fishery resource through community-based approach in Asia Pomeroy (1995) is a pointer that if given relevant knowledge and training, the rural African women can be easily integrated into co-management resource programs.

From the contributions of Pomeroy (1995) and State of the World Population (2006), the following observations confirm that women should be trained in resource management. Firstly; that communities of fishers, under certain conditions, when left to their own devices regulate access and enforce rules through community-based institutions and social practices. Secondly; the observation that the solutions to the current problems in the fisheries sector does not rest within its traditional realm but amongst informed people acting in what they perceive to be in their own best interest. Thirdly; the fact that fisheries has been identified as a good entry point to implement community-based collaborative management of natural resources. Fourthly; community-based resource management has become a prominent way to involve resource users and utilize indigenous institutional arrangements and knowledge in natural resource management. Fifthly; there is the rising importance of fish trade and the need to eliminate unavoidable barrier that can exist between artisanal small-scale traditional fisheries and large-scale, capital-intensive commercial fisheries. Sixth; The growing realization of the need for increased participation by resource user in management, and the greater localized control over access to resource can be seen in the wide range of policies and programs through out the south East Asian region (Pomeroy, 1995). Seventh; the realization that involvement of resource users in policy making process is a development in itself, since it will promote human rights, equity, growth and reduction of pressure on the natural resource (State of the World Population, 2006). It will be necessary therefore that women should be trained at the three government levels. The training could be by workshop, seminars or enlightenment programs using the mass media. Other training strategies include among others; integration of resource management into built-in school counseling as done in Guanajuato in Mexico; attaching natural resource messages to the different types of health problems attended to in medical centers, as done In Madagascar where the message is linked with family planning.

\section{Prospects Of Women Trained In Resource Management}

The prospects include; one; some rural women are involved in the production of fishing gear, trained ones therefore, can adhere to the use of recommended net mesh sizes and fishing practices, thereby being able to stand against illegal and destructive methods of resource exploitation. Two; trained women will avoid trade in fisheries resources that come 
from unsustainable fisheries practices. (Seafood Watch, 2006). Three; such women can see the need to turn from the use of fuel wood to the use of cleaner sources of power such as solar energy, gas and kerosene for cooking. The destruction of wild habitat according to Mukherjee, (2002) is by far the greatest cause of extinction of fauna and flora. The rate of species extinction put at 25000 times the natural rate, needs to be arrested since life is interdependent in nature. Four; awakening to the need for conservation norms and environment friendliness. Five; inculcation of the concept of interdependence of nature and of an ecological mind that will create and appreciate ecological values; thereby able to support ecosystem-based and co-management approaches to aquatic resource management.

\section{CONCLUSION AND RECOMMENDATIONS}

Women occupy strategic place in the production, processing, trade and use of the fishery resource. This strategic place and position of women predisposes them to wield much influence on the fishery resource, hence the need for women to be well informed through training on fisheries matter, as this will enable them to see the need for sustainable fisheries exploitation. Also, women at all levels of social strata should be trained or exposed to natural resource management so that they can avoid fishery resource from unsustainable sources. This also implies that measures to identify fishery resource from unsustainable sources should be put in place. The mode of enlightenment could be through workshops, seminars or the mass media. In addition, natural resource management messages could be integrated into built-in school counseling programs, into the school curriculum, or attached to health care delivered to patients. Women trained in natural resource management stand good chance of stopping the destruction of mangrove, illegal fishing practices and use of wrong mesh sizes.

When participating in resource management programs women will contribute by bringing in their indigenous knowledge of the fishery and at the same time understand important information from the scientist and other stakeholders. Equipped with natural resource knowledge, women would then stand a better chance of influencing, and thereby, enforce sustainable fishery exploitation

\section{REFERENCES}

Alamu, S.O and Olowosegun, T. 2005 Poverty Alleviation and Rural development in Nigeria. A Gender perspective: In Araoye, P. A.. (ed.), 19th Annual Proceedings of the Fisheries Society of Nigeria(FISON) Ilorin $29^{\text {th }}-3^{\text {rd }}$ December, 2004: 142-148.

Communications from the Commission to the Council and the European Parliament (2000) Fisheries and poverty reduction Brussels 8-11-2000 724 final.

FAO (1998) Functional Agro biodiversity Integrated Pest Management, and Aquatic Life Management in Rice In: Kenmore, P. and M. Halwart (eds.). Proceedings of the FAO/CBO International Workshop on Opportunities, Incentives, and Approaches for the Conservation and Sustainable Use of Biological. Diversity in Agricultural ecosystems and Production Sustems. FAO, Rome, Italy.

FAO (2009). State of the World Fisheries and Aquaculture2008, Rome, Italy. http://://www.greenfacts.org/en/fisheries/1-2/03-marine-inlandresources.htm.Retrieved107102007).

Lackey, T.Robert (2005). Fisheries: History, Science and Management pp121-129. In: Water Encyclopedia: Surface and Agricultural Water, Jay H. Lehr and Jack Keely, editors, John Wiley and Sons, Inc; Publishers, New York, 781pp.

Mukherjee, R. (2002). Environmental Management and Awareness Issues. Sterling Publications Private Ltd. New Delhi. 290pp. 
Pomeroy, Robert S. (1995) Community-based and co-management institutions for sustainable coastal fisheries management in South East Asia Ocean and Management 27(3): 143162.

Seafood Watch (2004). Queen Conch. Seafood Report Final Queen Conch _ SFW_ac_final. doc.

Shalesha, A. and Stanley, V.A (2000) Involvements of Rural Women in Agriculture: An innovation approach. Naga. The ICLARM Quarterly 23 (3): 13 -17.

Shinkafi, B. A. (2007) Women Participation in Fisheries in some fishing communities in Sokoto, Nigeria. In Araoye, Adikwu and Banke(eds.) $22^{\text {nd }}$ Annual Conference of the Fisheries Society of Nigeria, Kebbi, $12^{\text {th }}-16^{\text {th }}$ November; 2007: $233-235$.

Speer, L. (1995) Marine Fisheries, Population and Consumption: Science and Policy Issues. National Resources Defence Council Publication. 19pp.

State of the World Population, 2006 www.unfpa.org/swp/2001/english/cho6.html/3/4/2008.

Stream (Support To Regional Aquatic Resources Management) www.streaminitrative.org/infoAboutSTREAM.html/3/4/20008

Sultana, Parvin and Thompson Paul (2005). Gender and Local Floodplain Management Institutions- A case study from Bangladesh. International workshop on Gender and collective Action 17-21 Oct, 2005, Chiang Mai, Thailand.

UNDP (2003) Mainstreaming Gender in water Management a Practical Journey to Sustainability: Shoji Nishimoto, A Resource Guide

World Bank (2009). Agriculture and Rural Development: http://go.worldbank.org/16MVA17580. Retrieved 04/07/09.

World Conservation Society(2006) $\underline{\text { http://archive }}$ wcs.org/globalconservation/Africa/Madagascar/freshwaterfishconservation.....Retrieve d $12 / 07 / 09$

Yarhere, M. (2005) A study of Women's participation in Fish Food Security and Poverty Alleviation in Lagos and Ogun State In (ed) Araoye, Proceedings of the 19th Annual Conference of the Fisheries Society of Nigeria(FISON) Ilorin, $29^{\text {th }}-3^{\text {rd }}$ December, 2004: $167-178$. 